Title: Detection of long-term landscape changes and trajectories in a Pannonian sand region: comparing landcover and habitat-based approaches at two spatial scales

Authors: Marianna Biró, · Katalin Szitár, · Ferenc Horváth, · István Bagi and· Zsolt Molnár

Marianna Biró (Corresponding author)

Institute of Ecology and Botany, Centre for Ecological Research, Hungarian Academy of Sciences

Alkotmány u. 2-4, H-2163 Vácrátót, Hungary

e-mail: biro.marianna@okologia.mta.hu phone: 00-36-30-399-4882, fax: 00-36-28-360-122/110

Katalin Szitár

Institute of Ecology and Botany, Centre for Ecological Research, Hungarian Academy of Sciences

Alkotmány u. 2-4, H-2163 Vácrátót, Hungary

Ferenc Horváth

Institute of Ecology and Botany, Centre for Ecological Research, Hungarian Academy of Sciences

Alkotmány u. 2-4, H-2163 Vácrátót, Hungary

István Bagi

University of Szeged Department of Biology

Közép fasor 52. H-6726 Szeged, Hungary

Zsolt Molnár

Institute of Ecology and Botany, Centre for Ecological Research, Hungarian Academy of Sciences

Alkotmány u. 2-4, H-2163 Vácrátót, Hungary

Date of the manuscript draft: 6. May 2013, Manuscript word count (including Abstract, Text and Fig. captions): 6369 


\title{
Detection of long-term landscape changes and trajectories in a Pannonian sand region: comparing land-cover and habitat-based approaches at two spatial scales
}

\author{
Marianna Biró, Katalin Szitár, Ferenc Horváth, István Bagi, Zsolt Molnár
}

Keywords: change detection analysis; habitat change; land-cover change; habitat continuity; regional scale

\author{
Abbreviations \\ CHD change detection
}

\begin{abstract}
A key driver of biodiversity loss is human landscape transformation. Change detection and trajectory analysis are frequently applied methods for studying landscape change. We studied to what degree habitatspecific change detection and trajectory analysis provide different information on landscape change compared to the analysis with land-cover statistics. Our research was carried out at two spatial scales (regional, $1800 \mathrm{~km}^{2}$, 360 random points; local, $23 \mathrm{~km}^{2}$, polygon-based maps) in the Kiskunság, Hungary. Spatio-temporal databases were prepared using historical maps, aerial photos and satellite images from 1783, 1883, 1954, and 2009. Local expert knowledge of landscape history and recent vegetation was used during the historical reconstructions.

We found large differences at both scales between land-cover based and habitat-specific analyses. Habitatspecific change detection revealed that grassland loss was not continuous in the different habitats, as land-cover based analysis implied. Ploughing affected open sand grasslands and sand steppes differently in different periods. It was only apparent from the habitat-specific analyses that from the grasslands only mesotrophic and Molinia meadows were relatively constant, up until the 1950s. The gradual increase in forest area revealed by land-cover CHD analyses was split into natural and anthropogenic processes by habitat-specific analyses. Habitat specific trajectory analysis also revealed ecologically important historical differences between habitats. Afforestation affected especially the open sand grasslands, whereas wetland habitats were relatively stable. The most important trajectory was the one in which closed sand steppes were ploughed during the $19^{\text {th }}$ century, and remained arable fields until present. Fifty percent of the regional trajectories of $18^{\text {th }}$ century open sand grasslands terminated in tree plantations at present, though $82 \%$ of the current open sand grasslands of the local site can be regarded as ancient.

We concluded that dividing land-cover categories into finer habitat categories offered an opportunity for a more precise historical analysis of key habitats, and could reveal important ecological processes that cannot be reconstructed with land-cover based analyses. It also highlighted habitat-specific processes making natural and social drivers better interpretable. Information on the diversity of habitat-histories may serve as a basis for spatially more explicit conservation management.
\end{abstract}

\section{Introduction}

One of the most important drivers of biodiversity loss is human landscape transformation (Vitousek et al. 1997, Foley et al. 2005). Since landscape change has deep roots in the past, ecological processes must be viewed in a historical context. The past also is a reference point not only for understanding the present landscape, but for planning or predicting the future (Käyhkö and Skånes 2006). Long-term study of past processes is important, because it can reveal continuity, interactions, turnover and degree of change at different levels, from within-community patch dinamics to landscape scale processes (Pickett and White 1985, Cale et al. 1989, Anand and Heil 2000, Antrop 2005, Orlóci 2009). Since natural arrangements are dynamic, natural pattern is best regarded as a manifestation of complex dynamic processes at work (Orlóci 2001). Land-use changes often generate non-stationary, context-dependent dynamics of vegetation, so some land-use historical time periods can have particular importance in local habitat transitions (Orlóci et al. 1993, Anand and Orlóci 1997, Somodi et al. 2004). 
In order to investigate the relationship between landscape change and ecological processes, changes in landscape pattern are studied most often with the help of a time-series of maps or remotely sensed data. The goals of such studies are mainly to measure the change in landscape structure, diversity, stability and fragmentation (see Gillanders et al. 2008 for a review), to assert a relationship to biodiversity loss (Cousins and Ericson 2002, Lindborg and Eriksson 2004), and to model landscape change and their underlying socioeconomic driving forces (Veldkamp and Lambin 2001, Houet et al. 2010, Nainggolan et al. 2012).

One of the most important and frequently applied methods for studying landscape transitions is change detection (CHD) analysis, which is based on transition matrixes derived from land-cover change statistics (Cousins 2001, Käyhkö and Skånes 2006, Ichikawa et al. 2006, Ojeda-Revah et al. 2008, Mikusinska et al. 2013). The other method used widely is the identification of landscape change trajectories (Käyhkö and Skånes 2006, Swetnam 2007, Orczewska 2009, Ruiz and Domon 2009, Frondoni et al. 2011). Landscape change trajectory analysis focuses more on processes than states or patterns (Kayhkö and Skånes 2006). The use of trajectories allows for a more qualitative representation of spatial data, where areas with the same land-cover class today can be thematically separated due to different land-use and land-cover history (Käyhkö and Skånes 2006). The analysis requires at least three points of time and is more complicated owing to the necessary grouping of change trajectories. As the approach is primarily retrospective, the focus is on the development of the present-day landscape (Käyhkö and Skånes 2008). The analysis is usually applied to temporal tracking of land-cover patches, and grassland or forest continuity (Orczewska 2009), to study succession (Cserhalmi et al. 2011), urbanization (Frondoni 2011), and even to quantify the variability of landscape fragment histories (Swetnam 2007, Eremiásová and Skokanová 2009).

Most studies on landscape change apply land-cover or land-use categories, because the available sources of cartographical and remotely sensed material support this approach. To prepare and analyze spatio-temporal datasets, large-scale historical (usually military) maps are used. Their keys mostly include categories on land cover and land use. The division of land-cover categories into finer habitat categories (e.g. plant communities, Natura 2000 habitats) offers an opportunity for a more precise historical analysis of certain key or endangered habitats. Grassland and forest categories of a land-cover classification system may include very different habitats.

Changes of certain habitat types may be very different due to abiotic and biotic conditions, or factors driving land-use change (Bürgi et al. 2004, Antrop 2005). Most studies of landscape-scale habitat change use the change detection method (Arce-Nazario 2007, Ojeda-Revah et al. 2008, Agnoletti 2007, Kowalska 2012). Habitat-specific change trajectory analysis, applied first by Käyhkö and Skånes (2006), offers a chance to carry out a spatially explicit analysis, to separate primary and secondary patches of a certain habitat or the causes and stages of processes at the habitat scale (e.g. differentiate between spontaneous forest encroachment and afforestation).

The goal of our study was to apply habitat-specific trajectory analysis to study landscape scale changes. Our goal was to find out to what degree habitat-specific CHD and trajectory analysis provides different information on major directions of landscape change compared to the analysis using traditional land-cover statistics. Can these analyses highlight trajectories that remain invisible in land-cover change analyses? We have selected a landscape in which both, forests and grasslands are represented by several types, whereas soil pattern and land use is heterogenenous at fine scale, and the landscape is highly dynamic (Biró et al. 2007). Since landscape changes tend to be scale-dependent, we carried out the analyses at two different scales, using a regional and a local sample area.

\section{Materials and methods}

\subsection{Study area}

We conducted our study in the central part of the Kiskunság sand ridge (Danube-Tisza Interfluve) in Hungary. Landscape changes were assessed at two spatial scales. The regional study area $\left(30 \times 60 \mathrm{~km}, 46^{\circ} 27^{\prime}\right.$ $\left.-47^{\circ} 0{ }^{\prime} \mathrm{N} ; 19^{\circ} 15^{\prime}-19^{\circ} 39^{\prime} \mathrm{E}\right)$ was selected from the central and most characteristic part of the Kiskunság sand ridge at the larger scale, while for the smaller scale, a $4.8 \times 4.8 \mathrm{~km}$ sample quadrat $\left(46^{\circ} 52^{\prime}-46^{\circ} 55^{\prime} \mathrm{N} ; 19^{\circ} 23^{\prime}\right.$ 
$-19^{\circ} 27^{\prime} \mathrm{E}$ ) near the village of Fülöpháza was used (Fig.1). The Danube-Tisza Interfluve is a lowland alluvial fan between the Danube and Tisza Rivers deposited by the Danube River. It is composed primarily of sand and loess layers that were rearranged by wind several times during the Pleistocene and Holocene. The main soil types are calcareous sand soils with humus content below 3\% (Csecserits et al. 2011). Soils affected by the groundwater table and have high salt content cover large areas. The climate is continental with annual temperature of $10-11{ }^{\circ} \mathrm{C}$. The annual precipitation is $550-600 \mathrm{~mm}$ with increasing semi-aridity towards the central part of the area. This area is part of the forest-steppe biome in the Pannonian biogeographic region with a mosaic of several dry and wet, and salt affected habitat types due to diverse abiotic patterns (Kovács-Láng et al. 2000). The natural vegetation has been exposed to intensive human impacts for at least two millennia resulting in a highly fragmented landscape. Natural forest elements of the original forest-steppe vegetation almost completely disappeared by the $18^{\text {th }}$ century (Molnár et al. 2012). The area is characterized by widespread small-scale farming from the second half of the $18^{\text {th }}$ century with a peak extension in the 1950 's. The groundwater table has decreased significantly due to drainage and irrigation since the 1960's. This has led with parallel socio-economic changes to farm and land abandonment and degradation of wet habitats. The present landscape is dominated by agricultural areas, semi-natural grasslands and non-native tree plantations. The local site includes a vegetation mosaic similar to that of the study site at the regional scale. However, it is characterized by a higher proportion of wet habitats with salt lakes and marshes, which have degraded dramatically during the second half of the $20^{\text {th }}$ century, while extensive Molinia meadows are missing.

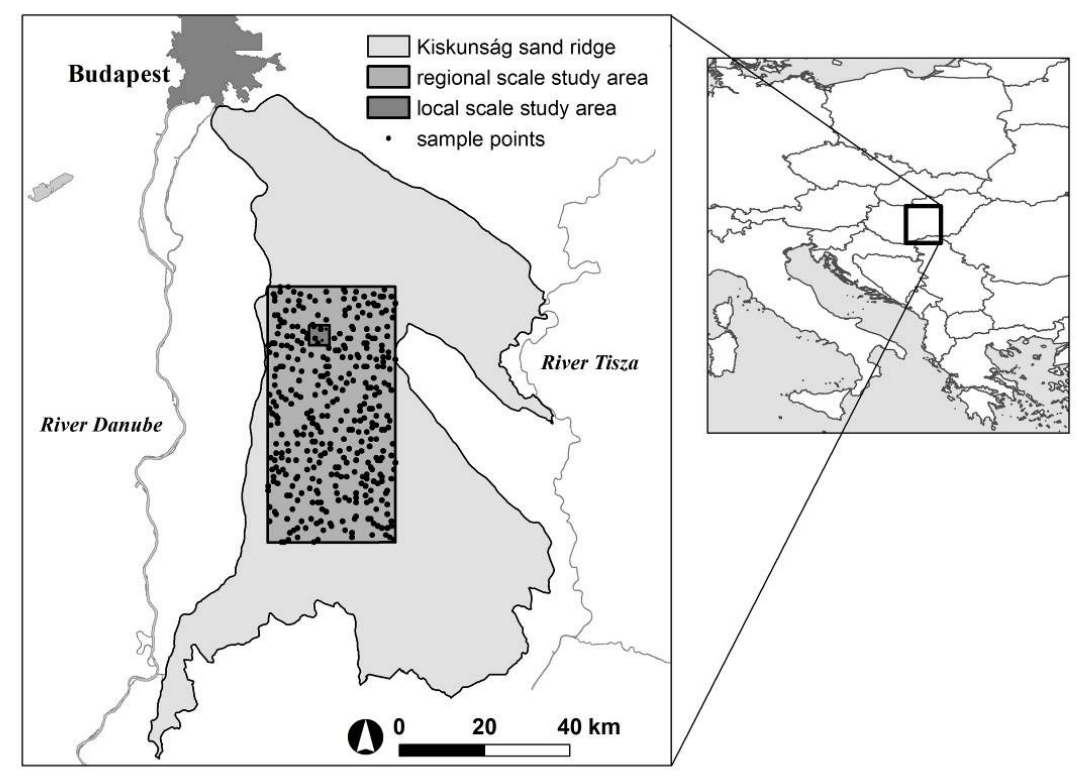

Fig.1. Location of the study area

\subsection{Data analyses}

\section{Regional scale}

Within the 30x60 km sample area (Fig.1), we randomly selected the center of 360 grid cells from the grid system of the MÉTA actual habitat database of Hungary (out of the 5225 grid cells, each with an area of 35 hectares, Molnár et al. 2007). For choosing the studied time periods, we relied on cartographical sources that represent landscape change at both scales, are broadly available, and cover large areas. These maps are the ones that have been used the most in time series studies in Central Europe. Thus, we chose the following times for this study: 1773-1774 (T1, I. Military Survey), 1883-1884 (T2, III. Military Survey), 1953-1959 (T3, Gauss- 
Krüger Topographic Military Map of Hungary), 2005-2010 (T4, BingMaps online, ArcGIS/BaseMaps). ArcGIS 10 software (ESRI) was used for managing datasets and maps and performing spatial analyses.

To describe temporal changes at each locality (center of grid cells), we assembled a spatio-temporal point database. Points falling on arable land, vineyard-orchard, built-in area or tree plantation on the historical maps were characterized by the key of the map source. Localities falling on natural or semi-natural landscape (one third of the total in T4) were classified into habitat types following the National Habitat Classification System (Á-NÉR, Bölöni et al. 2007, 2011). The types studied were as follows (Á-NÉR Habitat codes, and phytosociological units are also given): open sand grassland (G1, Festucetum vaginatae), closed sand steppe (H5b, Astragalo-Festucetum rupicolae), poplar-juniper scrub (M5, Junipero-Populetum albae), closed natural forest (M4, Populo canescenti-Quercetum roboris), mesotrophic wet meadow (D34, Cirsio cani-Festucetum pratensis), Molinia meadow (D2, Succiso-Molinietum hungaricae), uncharacteristic meadow (OB, mostly dried out, species poor mesotrophic meadows), uncharacteristic dry grassland (OC, mostly secondary grasslands on sand), uncharacteristic dry grassland invaded by non-native trees (Robinia pseudacacia and Ailanthus altissima), marsh (Phragmitetum australis, Bolboschoenetum maritimi) and lake. For this classification, we used data on habitats and habitat qualities from the MÉTA actual habitat database, our own field data, and data from the actual habitat mapping of the Danube-Tisza Interfluve (Biró et al. 2006).

Identification of past habitat types at the selected localities were accomplished by using the above mentioned cartographical and remotely sensed sources, as well as the digital elevation model (DEM-5, FÖMI-Budapest) and DEM-50 (srtm Worldwide Elevation Data available from Global Mapper Program). We also took into account our data on traditional ecological knowledge and landscape history, and considered topography, which greatly determines the environmental conditions of habitats (Biró and Molnár 1998, Molnár 2003). Correct interpretation of the historical sources that are not always precise (topographical errors can reach 50-100m) was facilitated by relatively stable topographical elements (roads, railroads, canals) and actual relief. Separation of open and closed sand grasslands was aided by a color difference on Corona satellite imagery (prepared in the 1960's), and aerial photographs from the 1950s. The soil color of arable land in former closed sand steppe appeared greyish, whereas that in open sand grassland was white. The classification was counterchecked by using the contour intervals of the DEM and the maps, and the representations of windblown sand and sand dunes on the map sheets of the $2^{\text {nd }}$ Military Survey (1860s). In the case of wetlands, we took into consideration the past and present landscape environment and its current natural vegetation (MÉTA, (Molnár et al. 2007), DT-Map (Biró et al. 2006) and field observations), and the direction of underground water flow (Mádl-Szőnyi and Tóth 2009), in addition to the map keys. We used the categories (grassland, forest, wetland, arable land, vineyard-orchard, settlement) depicted on the historical maps for the land-cover analyses. We constructed transition matrices from the point database, which we used to CHD analysis. Trajectories were described as snap-shot sequences of land-cover or habitat types according to the time periods represented by the historical maps (i.e. GGFF means grassland in T1, T2 and forest in T3 and T4). The same CHD and trajectory analyses were carried out on the database of land-cover types as on the habitat database.

\section{Local scale}

The study area for the local scale analysis is the sample area of Fülöpháza $\left(23 \mathrm{~km}^{2}\right)$ No. 99 . of the National Biodiversity Monitoring System. It is located within the study area for the regional scale analysis (Fig.1). The sample area was subject to repeated habitat mapping (Bagi 2000, Szitár 2010) following a standardized protocol (Takács and Molnár 2009). Habitats were classified into categories according to the National Habitat Classification System (Á-NÉR, Bölöni et al. 2007, 2011). During habitat mapping, the mapper recorded the actual vegetation without considering information from historical cartographical sources.

To track changes, we prepared a series of polygon-based maps for four dates $(1783,1883,1954,2009)$. Land-cover categories were established on the basis of categories shown on the historical maps (grassland, forest, wetland, arable land, vineyard-orchard, built-in area). Habitat types of the three historical time periods were reconstructed from historical land-cover types using DEM-5, aerial photographs from 1954, present field knowledge, oral history data from local inhabitants, soil data, and knowledge of degradation and regeneration processes of habitat types. We used DEM and the corresponding actual aerial photograph to improve the 
precision of the $18^{\text {th }}$ century habitat map. On the $18^{\text {th }}$ and $19^{\text {th }}$ century maps, there are still rather large continuous patches of grass-covered fields. Delimitation of habitat types within these patches was carried out with the help of DEM and soil coloration visible on the 1954 aerial photographs, rather than using later historical or current habitat maps. This way, the grassland and forest land-cover types were further divided into 8 habitat categories (see Fig. 2-5).

By step-by-step intersection of time layers of habitat maps, we assembled a spatio-temporal polygon database. Polygons smaller than $1000 \mathrm{~m}^{2}$ or with an area/perimeter ratio under 7 were considered as sliver polygons. These small, narrow-shaped polygons that appear along the borders of polygons have been eliminated after each step of intersection (by merging with the neighboring polygon with the longest border). We prepared transition matrices from the spatio-temporal polygon database, which we used in the CHD analysis. The transition matrices consist of transition probabilities of classes for all transitions from time to time by summarizing the areas of polygons of the same transitions. Trajectory analysis was carried out following the polygon-based model of Käyhkö and Skånes (2006). This concerns creation of one spatial dataset with intersecting polygons from all time slices. Each polygon possesses its own retrospective history, which means its trajectory. The analysis was based on the area of each different trajectory types. The same analyses were carried out on both, the database of land-cover types and the habitat database. Land-cover and habitat trajectories were described in the forward direction at the regional scale, and backward direction (retrospective way) at the local scale.

\section{Results}

\subsection{Change detection analysis}

\section{Regional scale}

By using the land-cover analysis, which is generally used in landscape change studies, we found that the area of grasslands declined by half during the first 100 years (T1-T2) at the regional scale. Grasslands were mostly transformed into arable land and forests (Fig. 2.a). In the next 70 years (T2-T3), grasslands declined by half again. Grassland patches changed into arable land, vineyards-orchards, and to a lesser extent forests. During the last 50 years (T3-T4), the extent of grasslands slightly increased (mainly arable land-grassland transitions). The significant increase in forest cover took place at the expense of grasslands during the first two periods, whereas during the third period mainly agricultural fields were transformed into forests.

The habitat-specific analyses revealed that the decline in grassland area took place in different periods depending on habitat type. During the first 100 years (T1-T2), mainly closed sand steppes were subject to destruction (ploughing) (Fig.2.b). The significant decline of open sand grasslands was the consequence of shrub encroachment rather than ploughing. The combined area of open sand grasslands and poplar-juniper scrubs virtually did not change during the first 100 years. The extent of Molinia meadows and mesotrophic wet meadows did not change substantially in this period either.

Between 1883 and the 1950s (T2-T3), the most apparent transition of all detected changes was the transformation of open sand grasslands into arable land and vineyards-orchards. Additional closed sand steppe patches were also claimed by agriculture. This trend resulted in the almost complete elimination of this habitat by the end of this period. Open sand grasslands and poplar-juniper scrubs were also transformed partly into tree plantations. The extent of Molinia meadows and mesotrophic wet meadows was virtually unchanged.

In the period from 1950s up until today (T3-T4), transformation of open sand grasslands and poplar-juniper scrubs into tree plantations also continued. The most pronounced change was afforestation which seemed to be the most extensive in former arable land and vineyard-orchard. Uncharacteristic dry grassland patches appeared in large numbers replacing vineyards and orchards. 

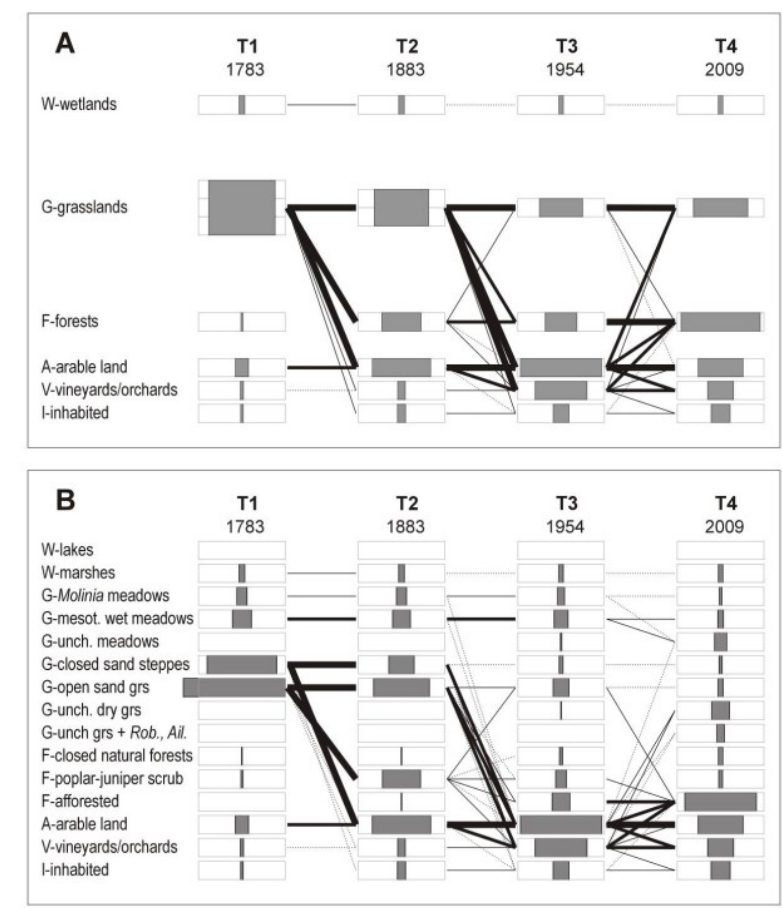

Fig.2. Change detection analyses of land-cover (A) and habitat types (B) of the regional study site of the Kiskunság sand ridge (Hungary) on the basis of spatio-temporal point database. Size of shaded boxes corresponds to the percent of land-cover/habitat types (thin lined boxes indicate $40 \%$ of the total number of point localities). Width of lines corresponds to the percent of total land-cover/habitat transitions in a certain time period. Transitions larger than $10 \%$ are shown with thick lines, transitions between $5-10 \%$ with medium lines, $2-5 \%$ with thin lines and $1-2 \%$ with dotted lines.

\section{Local scale}

Land-cover analysis of the local study area also revealed a significant decline in grassland area during the first period (from 73 to 44\%) (Fig.3.a). The decline continued until the 1950s, after which the process was reversed. The major direction of decline was a change into forests and arable land, similar to what was found at the regional scale. During the T2-T3 period, transformation of grasslands into arable land (and to a lesser extent into vineyards-orchards and forests) was typical. Later, this transition almost disappeared, and the transition from arable land to grasslands and forests became dominant. All periods were characterized by transitions from grasslands to wetlands and vice versa. Compared to the regional scale, wetlands are present in the local study area in higher proportions, and therefore the above paths were more pronounced. The area was completely devoid of forests. In the T1-T2 period, forests appeared at the expense of grasslands. In the following period, area of forests decreased by changing into grasslands. In the T3-T4 period, the forested area increased again (mostly arable fields changed into forests).

According to the habitat-specific analysis (Fig.3.b) in the $18^{\text {th }}$ century, open sand grasslands covered about one third of the area. During the T1-T2 period, approximately half of them turned into poplar-juniper scrubs mapped as forest on the historical maps. The area of open sand grasslands further decreased to $20 \%$ of their original extent in the T2-T3 then T3-T4 periods. The largest decline of closed sand steppe took place in the T1T2 period, similarly to what was detected at the regional scale. The area of closed sand steppes decreased from $23.6 \%$ to $0.34 \%$ between $\mathrm{T} 1$ and $\mathrm{T} 4$. As opposed to the continuous decline of dry sand grassland, mesotrophic wet meadows were relatively constant. Nonetheless, salt lakes completely disappeared in the T3-T4 period (mostly changed into marshes and meadows), whereas uncharacteristic meadows turned up (68\% in place of mesotrophic wet meadows, and $20 \%$ in place of arable land). The transformations among the two wetland habitats and mesotrophic wet meadows are indicated by the crossing transitions in all time periods. Meanwhile, their total area remained about the same (32-38\% in the four time periods). The increase in forested area was 
similar to that at the regional scale. It was apparent here, however, that this resulted from forest and scrub development in sand grasslands at the beginning, which was later replaced by afforestation. Eighty percent of the tree plantations were established in sand grasslands until the $1950 \mathrm{~s}$, whereas after this time, arable land and vineyards-orchards were also involved into afforestation.
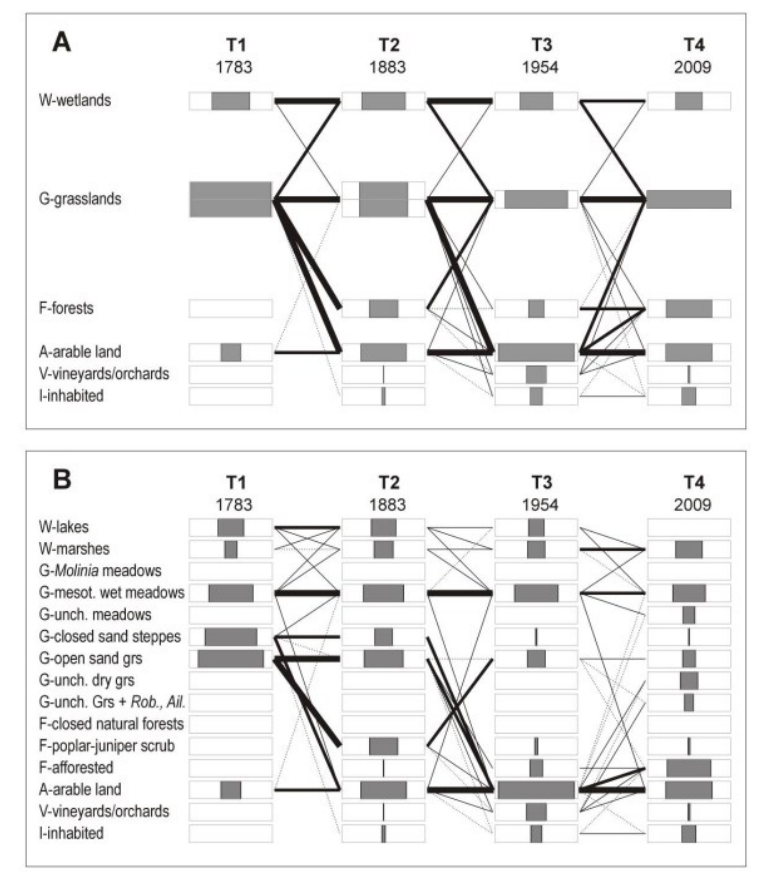

Fig.3. Change detecton analyses of land-cover (A) and habitat types (B) of the local study area (Fülöpháza, Hungary) on the basis of spatio-temporal polygon database. Size of shaded boxes corresponds to the area of land-cover/habitat types (thin lined boxes indicate $40 \%$ of the total area). Width of lines corresponds to the percent of area of total land-cover/habitat transitions in a certain time period. Transitions larger than $10 \%$ are shown with thick lines, transitions between $5-10 \%$ with medium lines, $2-5 \%$ with thin lines and $1-2 \%$ with dotted lines.

\section{2. Trajectory analysis}

\section{Regional scale}

According to the land-cover analysis at the regional scale (Fig.4.a), 10\% of the grassland area in the $18^{\text {th }}$ century remained grassland until the $21^{\text {st }}$ century (GGGG). The second and third most significant trajectories of grasslands were arable land from T2 (8.2\%, GAAA), and forest from T2 (7.8\%) (GFFF). Grasslands changed in T2-T3 period mostly in the directions of arable land or vineyards-orchards, and afterwards into forests or back to grasslands in T3-T4. There were very few forests in the area in the $18^{\text {th }}$ century (four points altogether), and thus their trajectories were not analyzed. Of the trajectories other than grasslands, continuously cultivated area $(30 \%)$ and continuous wetland habitat (14\%) were the most significant.

The habitat-specific trajectory analysis added further details to the result of land-cover analysis (Fig.4.b). The most important trajectory was the one in which the closed sand steppes of the $18^{\text {th }}$ century were ploughed during the period of T1-T2, and remained arable fields until present (11\% of all trajectories). We also documented a diversity of trajectories of low importance in open sand grasslands, but not in any other habitat. Of them, the trajectories of open sand grasslands turned into plantations in T2-T3 (with or without shrub encroachment), and those of open sand grasslands ploughed at the same time, then afforested later may deserve attention owing to their percentage above $6 \%$. Exactly half of the trajectories of $18^{\text {th }}$ century open sand grasslands ended as tree plantation in the present. Twenty two percent of all transformed closed sand steppe were ploughed during the first period and remained as such afterwards. The proportion of closed sand steppe ploughed similarly early, but eventually transformed into tree plantations or vineyards-orchards was also high 
(8-8\%). Ploughing the Molinia meadows was typical of the T2-T3 period, whereas ploughing the mesotrophic wet meadows was rather characteristic of the period of T3-T4. About one quarter of characteristic mesotrophic wet meadows and Molinia meadows became uncharacteristic during the T3-T4 period. However, the continuity of both mesotrophic wet meadow types can be regarded a similarly important trajectory.

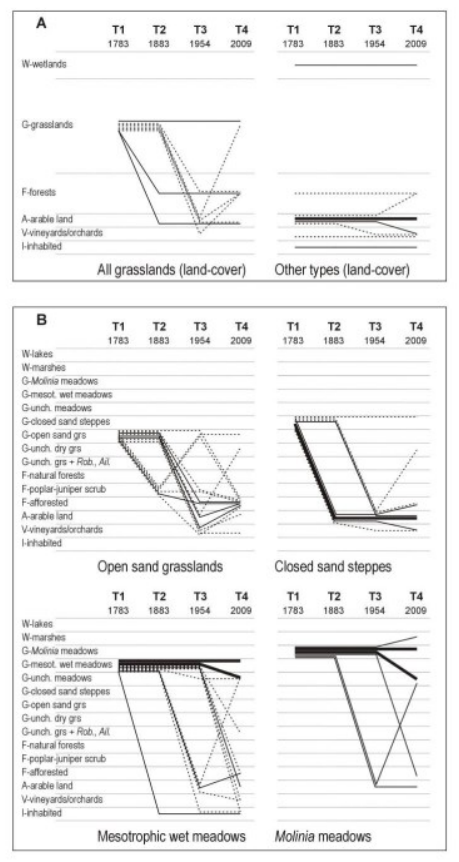

Fig.4. Trajectories of changes of the regional study site in the Kiskunság sand ridge (Hungary) on the basis of spatio-temporal point database from T1 to T4. Width of lines corresponds to percent of trajectories belonging to the certain land-cover/habitat category. Changes larger than $20 \%$ are shown with thick lines, transitions between 6-20\% with medium lines, 3-6\% with thin lines. A/ Trajectories of land-cover types (grasslands and other land-cover types). B/ Trajectories of the four main habitat types.

\section{Local scale}

At the local scale, we studied paths leading to currently existing grasslands and forests and some other important habitats in a retrospective way (Fig.5.a). Using the land-cover approach, the most pronounced path leading to current grasslands was continuous grassland (22\%). The second most important path was represented by grasslands ploughed by the 1950s (T2-T3) then abandoned later. Thirteen percent of the current grasslands were mapped in the $19^{\text {th }}$ century as forest (GFGG). A significant portion of the current grasslands were wetlands in the past (7.2\%, WWWG) and an additional $20 \%$ was wetland at least once. Another important trajectory leading to grasslands was vineyards/orchards established before 1950 and abandoned later (GGVG, GFVG). For the most part, forests developed from grasslands that were ploughed between T2 and T3, then were transformed into forests (GGAF 29\%). An additional 19 and 12\% of forests were those that changed from grasslands to forests during the T2-T3 or T3-T4 periods (GGFF, GGGF), respectively.

The habitat-specific approach provided additional details to the general picture (Fig.5.b). Thirty one percent of the open sand grasslands existed continuously throughout the last two centuries. Open sand grasslands with trajectories through poplar-juniper scrub (51\%), which is characterized by shrub encroachment at times, also is considered as semi-natural open sand vegetation. Thus, $82 \%$ of the current open sand grasslands can be regarded as ancient. Closed sand steppe, on the other hand, covers only $0.34 \%$ of the studied landscape, but $86 \%$ of it are considered as ancient. The most typical trajectories in the case of still existing mesotrophic wet meadows were the following: continuous meadows (23\%), meadows developed from salt lakes $(16 \%)$ and meadows developed from marshes that were meadows in certain periods of time (12\%). Trajectories switching between mesotrophic wet meadows and wetlands were also typical. We found $6 \%$ of the trajectories to involve 
arable land at some point of time. The most typical trajectory for present-day uncharacteristic meadows is continuous mesotrophic wet meadows turning into uncharacteristic meadows during the last time period (30\%). The second most frequent trajectory was the one with arable land in the 1950s (10\%). Trajectories involving some of all other wetland habitats were also frequent.

The most pronounced trajectories of present-day uncharacteristic dry grasslands started out of open sand grasslands or closed sand steppes (often through a poplar-juniper scrub stage). Their turning into arable land or vineyards took place between 1883 and 1950 (T2-T3). One quarter of the present uncharacteristic dry grasslands invaded by non-native trees developed from vineyards planted in place of open sand grasslands and abandoned between T3-T4. Trajectory analysis showed that $7-8 \%$ of present-day uncharacteristic dry grasslands and one-third of the grasslands invaded by non-native trees seem to be continuous. However, the actual vegetation of uncharacteristic dry habitats (Bagi 2000, Szitár 2010) showed that most of their area might have been under cultivation in the past. Their fine-scale history could only be revealed by a finer timeresolution analysis.

Three-fourth of the area of the uncharacteristic dry grasslands and $90 \%$ of the area of uncharacteristic dry grasslands invaded by non-native trees had trajectories starting from open sand grasslands in the $18^{\text {th }}$ century. At the local scale, $35 \%$ of the existing poplar-juniper scrubs developed from arable land or vineyards/orchards after abandonment, and only $64 \%$ can be regarded as continuously natural vegetation. All trajectories of poplarjuniper scrub started from open sand grasslands, and even the trajectories of the existing plantations on $70 \%$ of their area may be traced back to this habitat in the $18^{\text {th }}$ century.

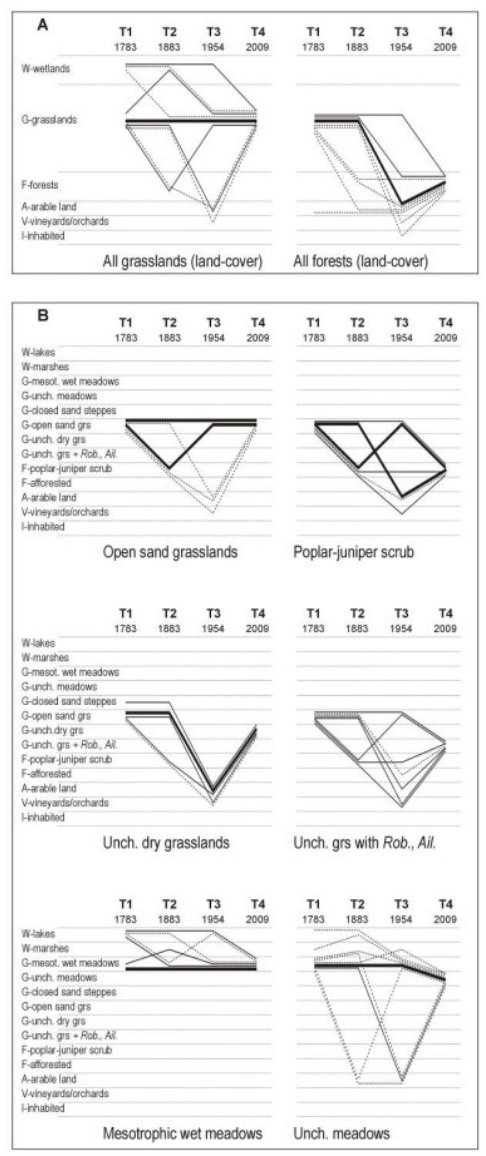

Fig.5 Retrospective trajectories of present-day land-cover/habitat types in the local study area (Fülöpháza, Hungary) on the basis of spatio-temporal polygon database. Width of lines corresponds to the percent of area of trajectories belonging to a certain land-cover/habitat category. Changes larger than $20 \%$ are shown with thick 
lines, transitions between 6-20\% with thin lines, 3-6\% with dotted lines. A/ Trajectories of present-day landcover types (grasslands and forests). B/ Trajectories of the main present-day habitat types.

\section{Discussion}

We found large differences between land-cover based and habitat-specific CHD analyses at both spatial scales. When using land-cover CHD, decrease of grasslands seemed to be continuous from T1 to T4. Habitat CHD analysis revealed that grassland loss was not continuous for the different habitat types. Changes in the three time periods could be explained by different processes and driving forces affecting habitats differently. Both, the regional and local-scale land-cover CHD analyses revealed that the cause of initial (T1-T2) decline in grassland area was transformation into forests and arable land. However, land-cover analyses did not show which type of grasslands became arable land or forest in this period. The habitat-specific analyses indicated that ploughing affected only one habitat type, the closed sand steppe. Ploughing was typical of the other main habitat type (open sand grassland) neither at the regional nor the local scale. This disparity between the two habitats may be explained by their differing soil quality, and thus their different suitability for agriculture (Kovács-Láng et al. 2000, Molnár et al. 2012). The fields on sandy soils with extremly low humus content were covered with open sand grasslands and were extensively grazed till the socio-economic changes at the end of the $19^{\text {th }}$ century (Biró, Molnár 1998, Molnár 2003).

According to the habitat-specific analyses at both scales, spontaneous shrub encroachment took place on open sand grasslands during the $19^{\text {th }}$ century. The exact cause of the process is still unknown. We suppose that a change in the grazing system (a switch from grey cattle to sheep) may have been a major factor in the spread of poplar-juniper and partly poplar-hawthorn scrubs (Biró 2008). These scrubs were depicted on the historical maps as forests. For military purposes, patches of woody vegetation covering only $20-30 \%$ of the surface were mapped possibly as forests in this otherwise almost treeless landscape (Biró and Molnár 1998). The map key, however, did not include any indication of vegetation density. These analyses also clearly showed that poplarjuniper scrub only developed from open sand grasslands in the $19^{\text {th }}$ century.

According to land-cover CHD analysis, the initial loss in grassland area was followed by further transformation of grassland into arable land and (at the regional scale also into vineyards-orchards) in the T2T3 period. The habitat-specific analysis pointed out that decrease of closed sand steppes continued, and open sand grasslands also started to decline. The main driver of this process was inhabitation of drifting sand dune areas (mainly by impoverished people from villages and towns) (Molnár 2003). An important part of stabilization of drifting sand in the region was the transformation of open sand grasslands on poor-fertility soil into vineyards and orchards (it was subsidized by the government in the first part of the $20^{\text {th }}$ century). Farm establishment began slowly in the T1-T2 period on fertile soils that were usually covered with closed sand steppes. Transformation of open sand grasslands took place only afterwards, mainly during the first half of the $20^{\text {th }}$ century. Between the years of 1883 and 1950, all closed sand steppe remnants with the exception of communal pastures and military grounds were claimed by agriculture. Today only those exist that managed to survive until their placement under legal nature protection (Biró et al. 2013).

On the basis of the regional habitat CHD analysis, $92 \%$ of the open sand grasslands was lost during the last 200 years (see also Biró 2008). Habitat trajectories showed that fifty percent of them have been turned into tree plantations. It was noticeable that those that survived till today had a large variety of non-marked trajectories. This calls the attention to the varied past history and high diversity of land-use change in sand dune areas.

It was apparent from the land-cover CHD analyses at both scales that cultivated areas often turned into grasslands or forests after the 1950s (T3-T4). These analyses only showed that grasslands mostly developed from arable land and to a lesser extent from vineyards-orchards. Habitat CHD revealed that mainly uncharacteristic dry grasslands (some with encroaching non-native trees) developed on these cultivated lands. Habitat-specific trajectory analyses, in turn, indicated that these areas were originally mainly open sand grasslands and poplar-juniper scrubs. These habitats were ploughed at the latest, and abandoned the earliest. There were two important reasons for this. First, the cultivation of these soils became uneconomical by the second half of the $20^{\text {th }}$ century due to the generally observed drop of the groundwater level (Biró et al. 2013). Second, abandonment was fostered also by the emigration of people living on farms (Csatári, Farkas 2008). 
Habitat-specific trajectory analyses also revealed hidden habitat destruction. Thirteen percent of the area mapped as open sand grassland at the local scale was in fact abandoned field less than 50 years old. The secondary origin was sometimes not detectable in the field, due to the high regeneration potential of the open sand habitat (Bartha et al. 2008, Szitár et al. 2008, Csecserits et al. 2011).

It was clear from both, the regional and local land-cover CHD analyses that wetland habitats were relatively stable. However, it was only apparent from the habitat-specific analyses that only mesotrophic wet meadows and Molinia meadows were relatively constant of the grasslands up until the 1950s. These areas were worthy of ploughing only after draining them in the 1960s, and following the droughts in the 1980s (Bagi 1988). The process was accelerated by governmental subsidies in the 1990's. In the analyses at the local scale, it is also apparent that the vegetation of salt lakes also underwent transformation and developed mainly into marshes and meadows by the $21^{\text {st }}$ century. This change was elicited by the leaching of salts from the upper soil layer after the long drought periods. In contrast to salt lakes, the constancy of Molinia meadows is remarkable. These meadows receive their water supply from below, mainly from the dunes (Mádl-Szőnyi and Tóth 2009). Owing to regular water cover, it was not worth of ploughing them. Mesotrophic wet meadows had a greater chance to get ameliorated, overseeded, or ploughed. Rather significant loss of Molinia meadows at the regional scale was generated by the first drainage works during the first half of the $20^{\text {th }}$ century. After digging the major canal in the area, the water of the nearby Molinia meadows was easily drained.

In the $18^{\text {th }}$ century, the study area was almost devoid of forests. This was confirmed by both types of analyses at both scales. However, the gradual increase in forest area revealed by land-cover CHD analyses was separated into natural and anthropogenic processes by habitat-specific analyses. During the period of T1-T2, open sand grasslands were spontaneously taken over by shrubs, then from T2, the increase in forest cover was attributed to afforestation and transformation to tree plantations. Afforestation began in the $19^{\text {th }}$ century to stabilize blowing sand, and continued after WWI to make up for the loss of mountain forests (Molnár 2003). In the second half of the $20^{\text {th }}$ century, afforestation on the poorest sandy soils with increasingly intensive methods was required in the socialist five-year plans.

The most pronounced changes detected in our study areas were grassland to forest and grassland to arable land ones in the earlier, and arable land to grassland or arable land to forest transitions in the later periods. These indicate land abandonment and afforestations in the last decades. Change detection studies carried out elsewhere also reported marginalization processes, mostly in mountain and marginal regions. The most pronounced transitions found are usually arable land to forest and arable land to grassland transformations (Agnoletti 2007, Eremiásová and Skokanová 2009, Rodrigues 2010). Unexpectedly, we also detected this marginalization in our study area, although that lies close to large cities and even to the capital. The reason for this were partly the drop of groundwater table, and partly a centrally imposed demography policy (Molnár 2003, Csatári and Farkas 2008).

\section{Conclusions}

We demonstrated that habitat-specific CHD and trajectory analyses can reveal important landscape ecological processes that cannot be reconstructed with land-cover based analyses. They highlighted habitatspecific processes and showed considerable diversity in patch history of certain habitat types, making natural and social drivers better interpretable.

Our random point-based regional analysis proved to be successful in documenting regional scale landscape change. We found very similar results at the local scale. Using the forward direction trajectories of past habitats, historical habitat changes could be documented in spatially explicit paths. In the retrospective way, the history of present habitats became visible.

Most CHD studies (e.g. Cousins 2001, Rodrigues 2010, Mikusinska et al. 2013) use percent values of changes for each land-cover category in figures of CHD analyses (all transitions of a certain type add up to $100 \%$ ). In contrast, we suggest that processes could be better interpreted if all transitions of all types in a time period add up to $100 \%$ (Ichikawa et al. 2006). By this we can avoid to overemphasize the transitions of landcover/habitat types with small area. 
The analysis using only three time periods may have underestimated small-scale dynamics owing to the relatively long intervals between mappings (60-100 years). To investigate vegetation changes, it also could be valuable to consider a larger number of time periods and habitats (cf. Ichikawa et al. 2006, Rodrigues 2010).

Availability of historical maps in a digital format provides an opportunity to carry out CHD and trajectory analyses even at a country-wide scale. The larger the area studied, however, the greater the caution needed. The depths of site-specific expert knowledge may decrease, whereas automated GIS analyses may receive a greater emphasis. As was shown, land-cover analyses only indicate main trends. Even the changes and trajectories of the most important habitats may add up resulting in a homogenized history, and therefore the results may be misleading (see e.g. the locally wrong predictions in Verburg et al. 2010, Hatna and Bakker 2011). The challenge of change analysis lies in the combined uses of landscape information originating from variable sources (Biró and Molnár 1998, Biró 2006). Similarly to the experience of Käyhkö and Skånes (2006), ours (Biró and Molnár 1998, Biró 2006) also suggests that the relevance and ecological interpretation of revealed processes are strongly limited without detailed knowledge of the local landscape, data-specific and context sensitive analyses, and meticulous correction of historical sources.

Landscape trajectories have been found useful in practical management and conservation of valuable habitats and landscapes (Cousins 2001, Käyhkö and Skånes 2006, 2008, Mikusinska et al. 2013). Analysis of trajectories facilitates the identification of, for example, ancient grasslands, or grasslands in the stage of regeneration. Information on diversity of histories may serve as a basis for spatially explicit conservation management (Cousins and Ericsson 2002, Käyhkö and Skånes 2008). It can help to select areas to be protected, and thus may greatly contribute to a more efficient conservation management of key habitats (Ujházy et al. 2011, Kowalska 2012). Future restoration of semi-natural habitats is of growing importance according to the European Union Biodiversity Strategy to 2020. One of the first steps to this is to map long-term habitat changes on a scale as fine as possibile. Such maps will give baseline information on earlier habitat configurations, and will allow for planning ecological networks, green infrastructure and multifunctional landscape in the future (Käyhkö and Skånes 2008, Hooftman and Bullock 2012). Historic habitat maps and landscape trajectories are especially important in regions where the identification of target communities is not evident (Csecserits et al. 2011).

Prediction of future landscape changes requires the understanding and integration of past landscape trends, current landscape change processes and feedbacks, and the incorporation of plausible assumptions or scenarios (Houet et al. 2010, Verburg et al. 2010). In light of climate change, modelling the future possible transformations of certain habitats is getting to the forefront of research (Czúcz et al. 2011, Prentice et al. 2007). This requires knowledge of the natural and social factors that affected the habitats in the past (Bürgi et al. 2004). Thus, trajectory analysis may play a fundamental role in modelling sensitivity to climate change. This analysis may answer such questions as to what degree a habitat was stable on the long run, how much change it has already undergone, and whether there are either back and forth habitat transformations and alternating degradative and regenerative stages, or the habitat history is rather monotonous and trend-like.

We argue that habitat-specific trajectory analysis provides basic, valuable, and hardly replaceable information that help better understand the long-term landscape-scale ecological processes and develop a more sustainable system of landscape and nature conservation management.

\section{Acknowledgements}

We would like to express our thanks to Interspect Kft., Kungeo Kft. and István Pánya for their help in preparing historical data sources for the analysis, Gábor Lendvai for English revision, the Kiskun LTER of the MTA Centre for Ecological Research and the Kiskunság National Park Directorate for archive aerial photos, remotely sensed sources and DEMs. This research was financed by the project "Sustainable Conservation on Hungarian Natura 2000 Sites (SH/4/8)" within the framework of the Swiss Contribution Program.

\section{References}

Agnoletti, M. 2007. The degradation of traditional landscape in a mountain area of Tuscany during the 19th and 20th centuries: implications for biodiversity and sustainable management. Forest Ecol. Manag. 249(1): 5-17. 
Anand, M. and G.W. Heil. 2000. Analysis of a recovery process: Dwingelose Heide revisited. Community Ecol. 1: 65-72.

Anand, M. and L. Orloci. 1997. Chaotic dynamics in a multispecies community. Environ. Ecol. Stat. 4(4): $337-344$.

Antrop, M. 2005. Why landscapes of the past are important for the future? Landscape Urban Plan. 70: 21-34.

Arce-Nazario, J.A. 2007. Human landscapes have complex trajectories: reconstructing Peruvian Amazon landscape history from 1948 to 2005. Landscape Ecol. 22: 89-101.

Bagi I. 2000. NBmR tájléptékű élőhely-monitorozás a “T5x5_099 Kiskunság/Fülöpháza” mintaterület élőhely-térképezése és leírása. Kutatási jelentés. (Habitat mapping and description of the $5 \times 5 \mathrm{~km}$ sample plot "T5x5_099 Kiskunság/ Fülöpháza" in the Hungarian Biodiversity Monitoring Project. Report in Hungarian). KvVM TvH, MTA ÖBKI, Vácrátót.

Bagi, I. 1988. The role of water management in the degradation processes of halophilic vegetation in Hungary. Environ. Conserv. 15: 359-362.

Bartha, S., Zs. Molnár and G. Fekete. 2008. Patch dynamics in sand grasslands: connecting primary and secondary succession. In: E. Kovács-Láng, E. Molnár, Gy. Kröel-Dulay and S. Barabás (eds.), The KISKUN LTER, Long- term ecological research in the Kiskunság, Hungary. Institute of Ecology and Botany, H.A.S., Vácrátót. pp. 37-40.

Biró, M. 2006. Történeti vegetációrekonstrukciók a térképek botanikai tartalmának foltonkénti gazdagításával (Reconstructions of historical vegetation by the method of ,teaching" maps). Tájökológiai Lapok. 4(2): 357-384. In Hungarian.

Biró, M. 2008. A Duna-Tisza köze fásszárú vegetációjának átalakulása a 18. század óta, különös tekintettel a száraz homokterületekre. (Changes in woody vegetation of the Duna-Tisza köze since the 18th century with special emphasis on sand dunes). In: Gy. Kröel-Dulay, T. Kalapos and A. Mojzes (eds.), Talaj-vegetáció-klíma kölcsönhatások. MTA Ökológiai és Botanikai Kutatóintézete, Vácrátót. pp. 23-38. In Hungarian.

Biró, M. and Zs. Molnár. 1998. A Duna-Tisza köze homokbuckásainak tájtípusai, azok kiterjedése, növényzete és tájtörténete a 18. századtól (Vegetation and land-use history in the sand dunes of the Duna-Tisza köze from the 18th century and the mapping of landscape types of the late 18th century). Történeti Földrajzi Füzetek. 5: 1- 34. In Hungarian with shortened English version.

Biró, M., A. Révész, F. Horváth and Zs Molnár. 2006. Point based mapping of the actual vegetation of a large area in Hungary description, usability and limitation of the method. Acta Bot. Hung. 48: 247-269.

Biró, M., A. Révész, Zs. Molnár and F. Horváth. 2007. Regional habitat pattern of the Danube-Tisza interfluve in Hungary I. The landscape structure and habitat pattern; the fen and alkali vegetation. Acta Bot. Hung. 49(3-4): 267-303.

Biró, M., B. Czúcz, F. Horváth, A. Révész, B. Csatári and Zs. Molnár. 2013. Drivers of grassland loss in Hungary during the postsocialist transformation (1987-1999). Landscape Ecol. 28(5) 789-803.

Bölöni J., Zs. Molnár and A. Kun. 2011. Magyarország élőhelyei. A hazai vegetációtípusok leirása és határozója. (Habitats of Hungary. A description and guide to Hungarian vegetation) MTA ÖBKI, Vácrátót. In Hungarian.

Bölöni, J., Zs. Molnár, E. Illyés and A. Kun. 2007. A new habitat classification and manual for standardized habitat mapping. Annali di Botanica nouva serie. 7: 105-126.

Bürgi, M., A.M. Hersperger and N. Schneeberger. 2004. Driving forces of landscape change - current and new directions. Landscape Ecol. 19: 857-868.

Cale, W.G., G.M. Henebry and J.A. Yeakley. 1989. Inferring process from pattern in natural communities. BioScience. 39(9): 600605 .

Cousins, S.A.O. 2001. Analysis of land-cover transitions based on 17th and 18th century cadastral maps and aerial photographs. Landscape Ecol. 16: 41-54.

Cousins, S.A.O. and O. Eriksson. 2002. The influence of management history and habitat on plant species richness in a rural hemiboreal landscape, Sweden. Landscape Ecol. 17: 517-529.

Czúcz, B., A. Csecserits, Z. Botta-Dukát, G. Kröel-Dulay, R. Szabó, F. Horváth and Zs. Molnár. 2011. An indicator framework for the climatic adaptive capacity of natural ecosystems. J. Veg. Sci.. 22(4): 711-725.

Csatári, B. and J. Farkas. 2008. Agrarian and Rural Development in Hungary, 1990-2005, In: Bańsky, J., M. Bednarek (eds.), Contemporary Changes of Agriculture in East-Central Europe. Polish Academy of Sciences Institute of Geography and Spatial Organization, Polish Geographical Society, Warsaw. (Rural Studies; 15.) pp: 147-164.

Csecserits, A., B. Czúcz, M. Halassy, G. Kröel-Dulay, T. Rédei, R. Szabó, K. Szitár and K. TöröK. 2011. Regeneration of sandy oldfields in the forest steppe region of Hungary. Plant Biosyst. 145: 715-729.

Cserhalmi, D., J. Nagy, D. Kristóf and D. Neidert. 2011. Changes in a wetland ecosystem: a vegetation reconstruction study based on historical panchromatic aerial photographs and succession patterns. Folia Geobot. 46(4): 351-371.

Eremiášová, R. and H. Skokanová. 2009. Land use changes (recorded in old maps) and delimitation of the most stable areas from the perspective of land use in the Kašperské Hory region. Landscape Ecol. 88(1): 20-34.

Fischer, J. and D.B. Lindenmayer. 2007. Landscape modification and habitat fragmentation: a synthesis. Global Ecol. Biogeogr. 16: 265-280.

Foley, J.A., R. DeFries, G.P. Asner, C. Barford, G. Bonan, S.R. Carpenter, ... and P.K. Snyder. 2005. Global consequences of land use. Science. 309(5734): 570-574.

Frondoni, R., B. Mollo and G. Capotorti. 2011. A landscape analysis of land cover change in the Municipality of Rome (Italy): Spatio-temporal characteristics and ecological implications of land cover transitions from 1954 to 2001. Landscape Urban Plan. 100(1-2): 117-128.

Gillanders, S.N., N.C. Coops, M.A. Wulder, S.E. Gergel and T. Nelson. 2008. Multitemporal remote sensing of landscape dynamics and pattern change: describing natural and anthropogenic trends. Prog. Phys. Geog. 32: 503-528. 
Hatna, E. and M.M. Bakker. 2011. Abandonment and expansion of arable land in Europe. Ecosystems. 14: $720-731$.

Hooftman, D.A.P. and J.M. Bullock. 2012. Mapping to inform conservation: A case study of changes in semi-natural habitats and their connectivity over 70years. Biol. Conserv. 145(1):30-38.

Houet, T., P.H. Verburg and T.R. Loveland. 2010. Monitoring and modelling landscape dynamics. Landscape Ecol. 25(2): $163-167$.

Ichikawa, K., N. Okubo, S. Okubo and K. Takeuchi. 2006. Transition of the satoyama landscape in the urban fringe of the Tokyo metropolitan area from 1880 to 2001. Landscape Urban Plan. 78: 398-410.

Käyhkö, N. and H. Skånes 2008. Retrospective land cover/land use change trajectories as drivers behind the local distribution and abundance patterns of oaks in south-western Finland. Landscape Urban Plan. 88(1): 12-22.

Käyhkö, N. and H. Skånes. 2006. Change trajectories and key biotopes - Assessing landscape dynamics and sustainability. Landscape Urban Plan. 75 (3-4): 300-321.

Kovács-Láng, E., Gy. Kröel-Dulay, M. Kertész, G. Fekete, S. Bartha, J. Mika, I. Dobi-Wantuch, T. Rédei, K. Rajkai and I. Hahn. 2000. Changes in the composition of sand grasslands along a climatic gradient in Hungary and implications for climate change. Phytocoenologia. 30(3-4): 385-407.

Kowalska. A. 2012. Changes in the area of protected plant communities in the middle vistula river valley in the second half of the 20th century, P. J. Ecol. 60(1): 19-30.

Lindborg, R. and O. Eriksson. 2004. Historical landscape connectivity affects present plant species diversity. Ecology. 85(7): 18401845.

Mádl-Szőnyi, J., and J. Tóth. 2009. A hydrogeological type section for the Duna-Tisza Interfluve, Hungary. Hydrogeology Journal 17(4): 961-980.

Mikusinska, A., B. Zawadzka, T. Samojlik, B. Jędrzejewska and G. Mikusiński. 2013. Quantifying landscape change during the last two centuries in Białowiez a Primeval Forest. Appl. Veg. Sci. 16: 217-226.

Molnár, Zs. (ed.) 2003. A Kiskunság száraz homoki növényzete (Sanddunes in Hungary, Kiskunság). Természetbúvár Alapítvány Kiadó, Budapest. In Hungarian

Molnár, Zs., M. Biró, S. Bartha and G. Fekete. 2012. Past Trends, Present State and Future Prospects of Hungarian Forest-Steppes. In: M.J.A. Werger, and M.A. van Staalduinen (eds.), Eurasian Steppes. Ecological Problems and Livelihoods in a Changing World. Springer, Dordrecht, Heidelberg, New York, London. pp. 209-252.

Molnár, Zs., S. Bartha, T. Seregélyes, E. Illyés, G. Tímár, F. Horváth, A. Révész, A. Kun, Z. Botta-Dukát, J. Bölöni, M. Biró, L. Bodonczi, J.Á. Deák, P. Fogarasi, A. Horváth, I. Isépy, L. Karas, F. Kecskés, Cs. Molnár, Ortmann-né A. Ajkai and S. Rév. 2007. A grid-based, satellite-image supported, multi-attributed vegetation mapping method (MÉTA). Folia Geobot. $42: 225-247$.

Nainggolan, D., J. de Vente, C. Boix-Fayos, M. Termansen, K. Hubacek and M.S. Reed. 2012. Afforestation, agricultural abandonment and intensification: Competing trajectories in semi-arid Mediterranean agro-ecosystems, Agr. Ecosyst. Environ. 159: 90-104.

Ojeda-Revah, L., G. Bocco, E. Ezcurra and I. Espejel. 2008. Land-cover/use transitions in the binational Tijuana River watershed during a period of rapid industrialization. Appl. Veg. Sci. 11: 107-116.

Orczewska, A. 2009. Age and Origin of Forests in South-western Poland and their Importance for Ecological Studies in Mandominated Landscapes. Landscape Res. 34 (5)

Orlóci, L. 2001. Pattern dynamics: an essay concerning principles, techniques, and applications. Community Ecol. 2(1): 1-15.

Orlóci, L. 2009. Multi-scale trajectory analysis: powerful conceptual tool for understanding ecological change. Frontiers of Biology in China. 4(2): 158-179.

Orlóci, L., M. Anand, and X.S. He. 1993. Markov chain: a realistic model for temporal coenosere. Biometrie-Praximetrie. 33: 7-26.

Pickett, STA and P.S. White. 1985. The ecology of natural disturbance and patch dynamics. Academic Press New York, New York, USA.

Prentice, I. C., A. Bondeau, W. Cramer, S.P. Harrison, T. Hickler, W. Lucht, S. Sitch, B. Smith and M.T. Sykes. 2007. Dynamic global vegetation modeling: quantifying terrestrial ecosystem responses to large-scale environmental change. In: J.G. Canadell, D.D.E. Pataki and L.F.Pitelka, Terrestrial ecosystems in a changing world. Springer, Berlin, Heidelberg. pp. 175-192.

Rodrigues, P. 2010. Landscape changes in Castro Laboreiro: from farmland abandonment to forest regeneration. MSc Thesis, Faculdade de Ciências da Universidade de Lisboa, Lisboa.

Ruiz, J. and G. Domon. 2009. Analysis of landscape pattern change trajectories within areas of intensive agricultural use: case study in a watershed of southern Que'bec, Canada. Landscape Ecol. 24: 419-432.

Somodi, I., K. Virágh and R. Aszalós. 2004. The effect of the abandonment of grazing on the mosaic of vegetation patches in a temperate grassland area in Hungary. Ecol. Complex. 1(2): 177-189.

Swetnam, R.D. 2007. Rural land use in England and Wales between 1930 and 1998: Mapping trajectories of change with a high resolution spatio-temporal dataset. Landscape Urban Plan. 81: 91-103.

Szitár K. 2010. Jelentés a “T5x5_099 Kiskunság/ Fülöpháza” NBMR kvadrat 2009-2010. évi újratérképezéséről. Kutatási jelentés. (Report of the remapping and description of the 5x5 km sample plot "T5x5_099 Kiskunság/Fülöpháza" in 2009-2010. Research report, in Hungarian.). KvVM TvH, MTA ÖBKI, Vácrátót.

Szitár, K., K. Török and R. Szabó. 2008. Vegetation composition changes in ex-arable fields following glyphosate application: the role of soil seed bank and timing of seed production. Cereal Res. Commun. 36: 1-4. (Suppl.)

Takács, G. and Zs. Molnár. (eds.) 2009. Habitat mapping. Handbooks of National Biodiversity Monitoring System IX. MTA ÖBKI KvVM, Vácrátót - Budapest. http://novenyzetiterkep.hu/?q=magyar/publikaciok/node/374 
Ujházy, K., J. Fanta, and K. Prach. 2011. Two centuries of vegetation succession in an inland sand dune area, central Netherlands. Appl. Veg. Sci. 14(3): 316-325.

Veldkamp, A. and E.F. Lambin 2001. Predicting land-use change. Agric. Ecosyst. Environ. 85: 1-6.

Verburg, P.H., D.B. van Berkel, A.M. van Doorn, M. van Eupen, and H.A.R.M. van den Heiligenberg. 2010. Trajectories of land use change in Europe: a model-based exploration of rural futures. Landscape Ecol. 25:217-232.

Vitousek, P.M., H.A. Mooney, J. Lubchenco and J. M. Melillo. 1997. Human domination of earth's ecosystems. Science. 277: 494499.

\section{Figure captions}

Fig.1. Location of the study area

Fig.2. Change detection analyses of land-cover (A) and habitat types (B) of the regional study site of the Kiskunság sand ridge (Hungary) on the basis of spatio-temporal point database. Size of shaded boxes corresponds to the percent of land-cover/habitat types (thin lined boxes indicate $40 \%$ of the total number of point localities). Width of lines corresponds to the percent of total land-cover/habitat transitions in a certain time period. Transitions larger than $10 \%$ are shown with thick lines, transitions between $5-10 \%$ with medium lines, $2-5 \%$ with thin lines and $1-2 \%$ with dotted lines.

Fig.3. Change detecton analyses of land-cover (A) and habitat types (B) of the local study area (Fülöpháza, Hungary) on the basis of spatio-temporal polygon database. Size of shaded boxes corresponds to the area of land-cover/habitat types (thin lined boxes indicate $40 \%$ of the total area). Width of lines corresponds to the percent of area of total land-cover/habitat transitions in a certain time period. Transitions larger than $10 \%$ are shown with thick lines, transitions between $5-10 \%$ with medium lines, $2-5 \%$ with thin lines and 1-2\% with dotted lines.

Fig.4. Trajectories of changes of the regional study site in the Kiskunság sand ridge (Hungary) on the basis of spatio-temporal point database from $\mathrm{T} 1$ to $\mathrm{T} 4$. Width of lines corresponds to percent of trajectories belonging to the certain land-cover/habitat category. Changes larger than $20 \%$ are shown with thick lines, transitions between 6-20\% with medium lines, 3-6\% with thin lines. A/ Trajectories of land-cover types (grasslands and other land-cover types). B/ Trajectories of the four main habitat types.

Fig.5 Retrospective trajectories of present-day land-cover/habitat types in the local study area (Fülöpháza, Hungary) on the basis of spatio-temporal polygon database. Width of lines corresponds to the percent of area of trajectories belonging to a certain land-cover/habitat category. Changes larger than $20 \%$ are shown with thick lines, transitions between 6-20\% with thin lines, 3-6\% with dotted lines. A/ Trajectories of present-day landcover types (grasslands and forests). B/ Trajectories of the main present-day habitat types. 